Journal of Life Economics

Cilt / Volume 7, Say1 / Issue 2, 2020, pp. 135-150

E - ISSN: 2148-4139

URL: https://www.ratingacademy.com.tr/ojs/index.php/jlecon

DOİ: https://doi.org/10.15637/jlecon.7.009

Araştırma Makalesi/Research Article

\title{
MILLENNIAL VERSUS NON-MILLENNIAL USERS: CONTEXT OF CUSTOMER ENGAGEMENT LEVELS ON INSTAGRAM STORIES (EXTENDED VERSION) ${ }^{1}$
}

\author{
Khalil ISRAFILZADE* \& Najaf BABAYEV** \\ * Vytautas Magnus University, LITHUANIA \\ e-mail: khalil.israfilz@gmail.com \\ ORCID: https://orcid.org/0000-0001-8228-4024 \\ ** Vytautas Magnus University, LITHUANIA \\ e-mail: najaf.babayev@vdu.lt \\ ORCID: https://orcid.org/0000-0002-1690-8617
}

Received: 11 March 2020; Accepted: 23 April 2020

\begin{abstract}
Ephemeral social media platforms, which displays rich media, primarily images and videos, are only available only for a short period of time. It has recently attracted researchers 'attention to better understand how ephemeral social media platforms impact users of social media. We design quantitative survey study that sampling data collected over two weeks $(N=149)$ to understand engagement differences (consuming, participating, producing) between Millennials and Non-millennials (the Silent Generation, the Baby Boomers, Generation X), on one of the leading ephemeral mobile platforms - on Instagram "Stories". Our data demonstrated that Millennials show statistically significant differences by engaging Instagram "Stories" than Non-millennials. However, results unexpectedly demonstrate that non-millennial (age 40 and more in 2020) users show the same engagement level in "watching" and "reading" ephemeral content as Millennial users.
\end{abstract}

Keywords: Instagram Stories, Customer Engagement, Ephemeral Social Media, Usergenerated content, Millennials

Jel Codes: M3, M30, M31, M37

\footnotetext{
${ }^{1}$ The following paper is an extended version of the conference proceedings publication [Israfilzade, K. and Babayev, N., 2019. Millennials versus non-millennials: the context of engagement levels on Instagram stories. In Challenges of globalization in economics and business: 4th international scientific conference, Georgia, Tbilisi, November 1-2, 2019: Ivane Javakhishvili Tbilisi State University]
} 


\section{INTRODUCTION}

Advanced technology has changed the lifestyle of individuals in the 21st century, where social media has become the most essential activity that adds more experience. This is due to the steady increase in the number of users around the world, which has increased the frequency of users from millions to billions on Social Media Platforms. Social media has become widely available, with monthly active users expected to reach 3.02 billion active users by 2021 (Chen and Cheung, 2019). There is a variety of social media networks that allow users, individuals or organizations, to be updated regularly and attached, including "Facebook", "Twitter", "Instagram", "YouTube", "Snapchat", "LinkedIn", etc. Social media continues to expand and add new features, replacing and improving old ones throughout their existence.

One of the latest trends and new user experience is ephemeral social media platforms that get popular every day by adding millions of users, which has recently attracted the attention of researchers (Bayer et al., 2016; Piwek \& Joinson, 2016; Billings et al., 2017; Belanche et al., 2019; Chen and Cheung, 2019; Vázquez-Herrero et al., 2019; van Nimwegen \& Bergman, 2019; Villaespesa \& Wowkowych, 2020). Modest definition of ephemeral social media allowing users to share post images and videos that can only be accessed for a short period of time (Bayer et al., 2016). Unlike social media platforms which provide permanent archiving posts, ephemeral social media platforms such as "Snapchat", "Instagram Stories", "Facebook Stories", "WhatsApp Stories", "YouTube Stories" allow an individual user to share content with auto-deletion for a limited time. Perhaps the most obvious aim of ephemeral sharing is to get an immediate user or viewer response.

Ephemeral content can be easily produced that there is no need for careful planning, staging and editing in contrast to permanent content. This is great for users because it indicates that they can remain engaged and stay on the radar of their audience while preparing more timeconsuming and demanding permanent content. Using filters, GIFs, music or masks makes presenting of content much more appealing and less intrusive than classic contents that consumers used to in social media (e.g., Facebook, Twitter)

Snapchat is one of the pioneering ephemeral social media platforms introduced in 2011 (Monteiro \& Mazzilli, 2016; Bayer et al., 2016; Xu et al., 2016) and soon became a widely known and very valuable tool for sharing moments in a short period of time for social media users. Due to the benefits of "Snapchat," corporations like "Twitter," "Instagram," "YouTube" have also implemented this function. Instagram Stories feature with 500 million active users is now the most popular ephemeral content in social media (Statista, 2019b). With the launch in August 2016, Instagram Stories are perhaps the most notable and innovative novelty of the late social network (Belanche et al. 2019). Thanks to its styling, structure and presence and different from most of the social networks, where users need to scroll their timeline, Instagram stories appearing to the full screen for 15 seconds. Then the user may follow a different story, and the user can move back and forth to previous and following stories in chronological order (Belanche et al., 2019).

Approximately two out of every three adults aged 18-29 use Instagram (Statista, 2019a) and this percentage has risen from 59 per cent to 64 per cent which shows how popular "Instagram" is in the younger generations. The latest studies demonstrate that new social media platforms are perfect tools for boosting brand reputation as well as to reach younger audiences (Sasha et al., 2016; Barry et al., 2016). Millennials are the most active users of the Ephemeral Social Media that this generation has grown in a time of economic rise, the drastic expansion of online social media platforms and online streaming services (Parment, 2013). However, scholars as Xu et al. (2016) and Cavalcanti et al. (2017) describe that it is essential to enlarge 
more researches in order to understand better how ephemeral social media platforms are affecting social media users.

Customer engagement has been the main topic for both practitioners and academics over the last decade. A range of scholars has suggested classifications of customer engagement in the social media that conclude plenty of online activities in a restricted number of categories (Calder, Malthouse \& Schaedel, 2009; Chu \& Kim, 2011; Brodie et al., 2011; Hollebeek, 2011; Vivek et al., 2012; Zhang \& Lee 2012; Luís Abrantes et al., 2013; Beckers et al., 2014; Fu, Wu, \& Cho, 2017; Pansari \& Kumar, 2017, 2018; Palmatier et al., 2018).

While some studies define customer engagement as behavioural manifestations beyond purchase (van Doorn et al., 2010), others argue that customer engagement is rather a psychological state of mind (Brodie et al., 2011). Customer engagement is indeed a critical element of the relationship marketing and reflects the strength of an individual's interest in and involvement in a company's products or events (Brodie et al., 2011; Vivek et al., 2012). However, there is a common opinion that customer engagement is a multidimensional term (Beckers et al., 2014) and can be holistically characterized as "the dynamics of the value of the customer in addition to the organisation, either by direct or indirect contribution" (Pansari \& Kumar, 2017).

One of the comprehensive researches made by Shao in 2009, his classification of user engagement includes consumption, participation and production (Shao, 2009). Furthermore, its dimensional type of online behaviour, which allows us to distinguish between behaviour according to the level of engagement of the user to the content.

Based on the previous researches (Bayer et al., 2016; Israfilzade, 2017; Belanche et al., 2019), our aim of the study is to determine the differences between Millennials and Nonmillennials in terms of their indirect contribution (Pansari \& Kumar, 2018) in the engagement classification (Shao, 2009) by consumption, participation and production in the case of Instagram Stories.

\section{RELATED WORKS}

\subsection{Ephemeral Social Media}

Consumers are likely to spend more time on social networks than watching TV; 50 per cent of the population use Facebook on a mediocre day, and only 39 per cent watch TV (Cooper, 2018). In fact, $40 \%$ of consumers agree that they are tracking favourite brands on social networks (Global Index, 2018). One of the main revolutionary features for social media was ephemeral contents in the ephemeral social media platforms (e.g., Snapchat, Instagram Stories). Considering that content disappears, self-awareness in communication often diminishes: there is no need to worry about unintended users and long-term content displays, users are more assured that they will "drop their guard" and post humorous information, including content that they may be reluctant to share on other social networks (Xu et al., 2016). There are plenty of causes why consumers love ephemeral content: the perfect fit for mobile devices; gives a sense of authenticity; avoids clogging up the main feed with content (Bayer et al., 2016; Belanche et al., 2019).

It is quite straightforward to see how temporary content influences the way in which individuals consume social media information and permit their attention to be drawn and tugged while they scroll, swipe, laugh and smile - and soon enough, they might disremember all about it. However, Nimwegen and Bergman (2019) also conducted experiments focused on the relationship between ephemerality and memory recognition. According to the study, in the ephemeral application, awareness of the ephemerality of the content resulted in better recognition memory for the images and longer viewing times. 
The content analysis (Vázquez-Herrero et al., 2019) of various online news media using Instagram Stories also showed increasing interest and insight in visual journalism. Content is used to direct users to a website, which is not different from the practice of the media on Facebook and Twitter.

Certain features make Snapchat and Instagram a popular instant messaging app. They are strictly a phone app (accessible on smartphones allowed by Apple iOS and Google Android) and therefore it cannot be used with the browser (as with Twitter or Facebook Messenger). Snapchat and Instagram Stories create a sense of urgency for their users to search the app constantly in order not to skip the content (VanDerslice, 2016). Snapchat - was the innovator for new norms in communication (several words; short, visual memes). According to research results (Piwek \& Joinson, 2016), people mostly post "selfies," usually add text and "doodles" with images that they send, use it most often at home, and mostly as an "easier and funnier" way of communicating with close friends and family.

There is also a new standard in how "I define relationships with others" (inclusion against relationships; acquaintances with friends/relatives; now against later; direct value against long-term value) (Sashittal et al., 2016). Rather than relying on the earlier large-format advertising format that people see, holding the mobile devices vertically, Snapchat asks advertisers to develop content that can be browsed when the mobile device is in a vertical position (i.e. in its natural position). This step signals: "We have the correct technology. We bring the audience. You, the advertiser, should change." (Sashittal et al., 2016). As a native mobile app, Snapchat is built on sharing images "on the go" and consequently depends on mobile phone mobility (Schrock, 2015). This mobility allows people to post their pictures regardless of time and place, that is essential given Snapchat's "modern" limitation.

Based on research (Sashittal et al., 2016) conducted amongst college students, the findings were as follows; the sweet spot refers to the feeling of equality, inclusiveness and simplicity and has the potential to encourage opportunities expansion. According to the same research conducted by students of the college, Snapchat is expected to be a perfect social network for the creation of brands of acquaintances: brands that aspire to become a part of inclusive, nice touch interaction or communications acquaintances to a large extent.

\subsection{Ephemerality on Instagram STORY}

Bypassing the number of more than 800 million active users globally, Instagram is leading the way with the largest growth in Western countries (Statista, 2018) with over one million advertisers. It's not only one of the most common virtual platforms, but also social media where people are likely to spend time (Sheldon \& Bryant, 2016); as numbers show users remain on Instagram more than other leading social media platforms: 45 per cent more than Facebook, and 40 per cent more than Twitter (Alter, 2018). The aim of Instagram differs from other social media platforms. Instagram is using the logic of individual self-promotion (Marcus, 2015) and pleasure (Casalo et al., 2017) in the social sphere.

In 2016, Instagram launched (Instagram, 2016) Instagram Stories feature as something that allows you;

" share all the moments of your day, not just the ones you want to keep on your profile".

Instagram's Stories feature works differently. While Snapchat was released with the introduction of "Stories" this feature was not released on Instagram until August 2016 and the visual elements of the app were completely changed. For example, Instagram shared statistics for January 2019; it reached 500 million daily active story users of its platform per day worldwide in comparison with 100 million for 2016 (Statista, 2019a). Also, most of the users (more than a half) are likely to be 34 years old and younger. 
Instagram Stories feature allows users to get an ephemeral relationship in a strictly consumer-controlled environment, in a place where users advertise themselves as individual brands (Sheldon and Bryant, 2016). Instagram's Story is styled around the logic of "sharing a moment" over a short period of time, only 24 hours. Story feature creates a need and desire to check their Instagram more often to be aware of the content uploaded by the users they subscribe until the content totally disappears (Belanche et al. 2019).

Instagram Stories are disappearing contents that combine videos and photos and create a slideshow gallery that tells a story. The content users chose for their Story will now be a series that their followers can swipe like a mini slide show on their devices for 24 hours until it disappears. For getting notified about the stories, content consumers will see a colourful circle next to their photos. Which means, their subscribers feed Instagram with new stories. All is needed to be done is a tap on the profile photo to see persons story.

Additionally, the study at the Brooklyn Museum by Villaespesa and Wowkowych (2020) also points out people's behaviours using Snapchat and Instagram stories. Ephemeral content (photography) often is motivated, just like previous photo-taking behaviour in the museum, by capturing a feeling, an aesthetically appealing museum artefact, sharing an image, and creating self-identity.

As Belanche's (2019) recent study results show, Instagram stories not only improve consumer attitudes toward advertisements but at the same time, changes perceived obsessions positively in compare to Facebook's wall. Millennials are more concerned about advertising on Facebook rather than non-millennial users. Non-millennial men are more loyal to Facebook advertisements when millennial users of both genders and women from non-millennial are more loyal to Instagram Stories advertisements (Belanche et al., 2019). Due to that, the same research results demonstrate that it is more goal-oriented to focus on Instagram stories when organisations target millennial and non-millennial women, and on the Facebook wall when organisations target non-millennial men.

\subsection{Development of Hypotheses}

Social media promote communication, collaboration and content sharing (Palmer 2009). In younger generations, along with Millennials, the use of ephemeral content promotes more communication (Saschittal et al., 2016). Millennials are the first generation to spend their life in a digital environment cause our age of information technology has a significant effect on how they live and work (Bennett et al., 2008; Wesner and Miller, 2008).

Someone born between 1981 and 1996 (age 24-39 in 2020) is known as a Millennial generation (Dimock, 2019). Additionally, anybody else born after 1997 is part of a new generation, called the $\mathrm{Z}$ generation. In comparison to these latest generations, according to Fry (2018) at Pew Research Center, previous generations are the Silent Generation (born 19281945); the Baby Boomers (born 1946-1964); and Generation X (born 1965-1981), which we define in our research as Non-Millennials.

Instagram Story statistics have the highest attendance among Millennial users (59\%). Still, while Generation Z (Gen Z) users watch more stories (72\% of users from Gen Z) watch "Stories" on Snapchat, in compare to (70\% of users from Gen Z) on Instagram (VidMob, 2018). Besides, according to the same report (VidMob, 2018), the percentage of Instagram users who create content on Instagram is significantly lower than those who consume the network's content $31 \%$ from Millennials and 39\% among Gen Z.

The content of the Ephemeral social media platforms is user-generated content (UGC) (Bayer et al., 2016). The definition of the UGC, widely known in 2005, is usually associated with a description of different types of media content that are publicly available and produced 
by end-users (Kaplan \& Haenlein, 2010). In the Organisation for Economic Co-operation and Development (OECD, 2007), UGC is defined as:

a) content made publicly available over the Internet,

b) which reflects a "certain amount of creative effort", and

c) which is "created outside of professional routines and practices".

According to Pansari and Kumar's (2017) customer engagement theory, if a user is satisfied with his / her interaction with the firm and has an emotional connection to the company, this can be assumed that the user is engaged with the company. In other ways, in order for the customer to be engaged, the customer should have a pleased and emotional connection with the company.

The classification of Shao (2009) by consumption, participation and production was found to be particularly useful. In essence, its dimensional nature from passive to more active forms of online activity, allows us to differentiate between actions on the basis of the effort required by the user and to validate a triple classification using elements from other classifications.

Consuming is perceived to be the most passive level of Instagram Stories utilization and engages the entirely passive use of online content for searching for information and entertainment, which is similar to watching TV or reading magazines (Jansz et al., 2015). Yoo and Gretzel (2011) also have mentioned in their study that the most dominant method of involvement is surfing and consuming UGCs but not contributing. By consuming it, they can express their care, be updated latest information, find new trends (Israfilzade, 2017). Buying goods from websites, watching photos or videos, playing an online game, and all of these show the activities we consider as a consumption.

H1: There is a statistically significant difference between Millennial users and NonMillennial users' consuming on Instagram Stories.

Shao (2009) states that people who exhibit "participating behaviour" share, evaluate, or comment only on existing content, whereas those who exhibit "producing behaviour" in creating new content. Fuchs (2013) mentioned in his book that a person who takes advantage of social media when evaluating and commenting could be recognized as a semi-active user. They may participate actively; however, they do not create any new and creative content in media. Participation includes actions that require more effort and engagement than consuming; nevertheless, that does not make it more challenging to perform in the actions, such as "tagging" a photo or assigning video stars. Shao (2009) argues that participation is often aimed at establishing and maintaining social relationships.

H2: There is a statistically significant difference between Millennial users and NonMillennial users' participating on Instagram Stories.

Shao, also (2009) suggests that the user-generated content is motivated by the need of self-estimation. The production demonstrates one of the most intense stages of Shao's categories and refers to users' new content to distribute on the given social media. Another way of involvement of UGC - creation and the publication of content (video, a photo, a podcast, music, the blog and the platform of social networks) created by itself (Shao, 2009). Also, Chu and Kim (2011) have explored eWoM (an electronic word from the mouth) on social media, and production can be classified as an opinion giving that opinion when an individual provides information to others and influences them through that information. 
In other words, from the latest book in "Customer Engagement Marketing" (Palmatier; Kumar \& Harmeling, 2018) we may assume producing on Instagram stories as;

"We capture, caption, edit, chronicle, and publicize mundane, personal experiences for an awaiting audience of loyal followers who will comment and redistribute to others who are often strangers."

H3: There is a statistically significant difference between Millennial users and NonMillennial users' producing on Instagram Stories.

\section{METHOD}

The SPSS statistical program was chosen to perform data analysis and test hypotheses. As a primary data collection, the survey questionnaire was accurate in order to achieve overall results. "Google Forums" have been used to gather responses to the survey to create a questionnaire. The questionnaire consisted of 12 questions which were formulated based on the related literature and divided into three groups of engagement level - consuming, participating and producing. Seven-point Likert scale question was chosen to collect more complete responses. Seven-point Likert scales are sensitive enough to gather a more precise assessment of the respondents and are more suitable for electronic distribution (Finstad, 2010). Each of the stated questions was responded on a seven-point Likert scale from Strongly Agree to Strongly disagree (Strongly Agree, Agree, Somehow Agree, Neutral, Somehow Disagree, Disagree, and Strongly Disagree).

Respondents were registered by using social media and email list after reaching through the online link for the questionnaire, which was posted on the university website, online platforms, shared with students (mostly master and $\mathrm{PhD}$ programs), colleagues during May 2019. For each respondent, a single survey was allowed that was accessible only one week. After rejecting 11 responses that did not meet criteria (we excluded generation $\mathrm{Z}$ ), the final sample consists of 149 individual results (Millennials $(n)=91$; Non-millennials $(n)=58$ ). Distribution of the gender was consequently Millennial female $(n)=52$ and male $(n)=39$; Nonmillennials female $(n)=37$ and male $(n)=21$.

\subsection{Measurement}

For the questionnaire, measuring scales were constructed from Shao's (2009) research on the theoretical content of respectively variable. Table 1. illustrates the measure which was used to analyse each construction and the foundation. First three questions (QC1, QC2, QC3) designed to evaluate the consuming level of the engagement by watching, reading and following in the Instagram Stories. Next part consists of the questions (QPA1, QPA2, QPA3) regarding the participating level of the engagement. The final part (QPR1, QPR2, QPR3, QPR4) purpose was to collect data for the producing level of the engagement. 
Table 1. Constructs, scale items and source.

\begin{tabular}{|c|c|c|c|}
\hline Construct & Item coding & Measurement & Adapted from \\
\hline Consuming* & $\begin{array}{l}\text { QC1. } \\
\text { QC2. } \\
\text { QC3. }\end{array}$ & $\begin{array}{l}\text { Watching Story } \\
\text { Reading Story } \\
\text { Exploring new hashtags and accounts }\end{array}$ & Shao (2009) \\
\hline Participating* & $\begin{array}{l}\text { QPA1. } \\
\text { QPA2. } \\
\text { QPA3. }\end{array}$ & $\begin{array}{l}\text { Answering Polls/ Questions } \\
\text { Sending message (commenting story) } \\
\text { Sharing other stories }\end{array}$ & \\
\hline Producing* & $\begin{array}{l}\text { QPR1. } \\
\text { QPR2. } \\
\text { QPR3. } \\
\text { QPR4. }\end{array}$ & $\begin{array}{l}\text { Taking photo/ recording video } \\
\text { Uploading photo/video } \\
\text { Creating Polls/ Questions } \\
\text { Stories Highlights (archiving) }\end{array}$ & \\
\hline
\end{tabular}

For testing the validity of the collected data (Table 2), it was also decided to test reliability and discriminant validity. By measuring Cronbach's alpha, was checked construct and composite reliability, and it was higher than 0.65 indexes as it is recommended (Steenkamp and Geyskens, 2006). Also, it was noted that the average variance extracted (AVE) are higher than 0.5 (Fornell \& Larcker, 1981). The sections of each measure were positively correlated. Furthermore, thanks to the corroborating, it was proved that the ratio among constructs was lesser than the square root of the AVE for respectively construct. (Foreland \& Larcker, 1981). As well, for distribution normality and the absence of multicollinearity problems, some tests were also done as it describes in Table 3. Skewness and Kurtosis values of \pm 2 , which means it matches the distribution normality (Garson, 2012). All the kurtosis values are in the acceptable range of \pm 10 (Kline, 2011).

Table 2. Reliability tests.

\begin{tabular}{lccc}
\hline & Cronbach's alpha & $\begin{array}{c}\text { Average variance extracted } \\
\text { (AVE) }\end{array}$ & $\begin{array}{c}\text { Composite reliability } \\
\text { (CR) }\end{array}$ \\
\hline Consuming & 0.81 & 0.73 & 0.89 \\
Participating & 0.69 & 0.82 & 0.60 \\
Producing & 0.72 & 0.83 & 0.72 \\
\hline
\end{tabular}

Correlations values, which are above 0.70 or 0.90 , considered as multicollinearity problems. Furthermore, according to Hair (1998) that the variance inflation factor for each item was under the recognised limit of 10. 
Table 3. Normality and multicollinearity tests.

\begin{tabular}{lccc}
\hline Item & Skewness & Kurtosis & VIF \\
\hline QC1. & -0.54 & 1.37 & 2.40 \\
QC2. & -0.47 & 0.51 & 1.74 \\
QC3. & -0.37 & 0.05 & 2.26 \\
QPA1. & -0.52 & 0.27 & 1.53 \\
QPA2. & -0.18 & 0.03 & 1.68 \\
QPA3. & -0.37 & -0.06 & 1.65 \\
QPR1. & -0.39 & -0.21 & 1.49 \\
QPR2. & -0.60 & 0.11 & 1.35 \\
QPR3. & -0.19 & -0.41 & 2.10 \\
QPR4. & -0.16 & -0.47 & 1.69 \\
& & & \\
Note: VIF = Variance inflation factor & & \\
\hline
\end{tabular}

\section{RESULTS}

For testing the effect on each dependent variable, it was decided to use ANOVA (analysis of variance) method, taking into account all the different conditions. As it is shown in Table 4. The results of the ANOVA analysis show that p-value is lower than 0.05 , as it is recommended for the items. Only two dependents exceeded given boarder. One of them is "Watching story" (QC1) with the p-value greater than 0.05 ( $p=0.12)$. "Reading story" (QC2) surpassed the border of 0.05 and demonstrated 0.41 at last. That means there is no significant difference for "Reading story" between Millennials and Non-Millennials in the questioner. For Millennials the standard deviation varies between on the table 0.90-1.27, for Non-Millennials these numbers vary between 0.83-1.21.

For testing the hypotheses, each of the collected data was grouped for each hypothesis and analysed with ANOVA method. P-value was lower than recommended 0.05, and two from the three hypotheses gave a final result of 0.00 in the table. Standard deviation numbers did not exceed 0.92. The minimal standard deviation number for both Millennials and Non-Millennials was 0.65 . Table 5 illustrates the result of hypotheses analyses.

Table 4. ANOVA analysis of items.

\begin{tabular}{l|c|c|c|c|c|c}
\hline \multirow{2}{*}{ Item } & \multicolumn{4}{|c|}{ Age } & \multicolumn{2}{c}{ ANOVA } \\
\cline { 2 - 5 } & \multicolumn{2}{|c}{ Millennials } & Non-Millennials & \multicolumn{2}{c}{ SD } \\
\cline { 2 - 6 } & Mean & SD & Mean & SD & 147) & -value \\
\hline QC1. & 5.08 & 1.27 & 4.76 & 0.96 & 2.48 & 0.12 \\
QC2. & 5.03 & 0.90 & 5.19 & 0.83 & 0.71 & 0.41 \\
QC3. & 4.68 & 1.10 & 4.21 & 1.12 & 6.47 & 0.01 \\
QPA1. & 5.40 & 0.96 & 5.02 & 0.76 & 6.39 & 0.01 \\
QPA2. & 5.35 & 0.90 & 4.31 & 0.92 & 46.60 & 0.00 \\
QPA3. & 4.81 & 1.06 & 3.95 & 1.21 & 21.09 & 0.00 \\
QPR1. & 5.70 & 1.02 & 4.53 & 0.96 & 48.92 & 0.00 \\
QPR2. & 5.51 & 1.18 & 4.83 & 0.96 & 13.52 & 0.00 \\
QPR3. & 5.36 & 0.94 & 4.17 & 0.98 & 55.33 & 0.00 \\
QPR4. & 5.46 & 0.91 & 4.17 & 1.01 & 65.12 & 0.00 \\
\hline
\end{tabular}

Results of the hypotheses testing (Table 5) shows that the hypothesis of supporting the significant difference between millennial users and non-millennial users consuming Instagram stories was not accepted. 
Table 5. Results of the hypotheses testing.

\begin{tabular}{l|c|c|c|c|cc|c}
\hline \multirow{2}{*}{ Hypothesis } & \multicolumn{4}{c|}{ Age } & \multirow{2}{*}{ ANOVA } & \multirow{2}{*}{ Results } \\
\cline { 2 - 5 } & \multicolumn{2}{|c|}{ Millennials } & \multicolumn{2}{|c|}{ Non-Millennials } & & & \\
\cline { 2 - 7 } & Mean & SD & Mean & SD & $F(1,147)$ & $p$-value & \\
\hline H1 (Consuming) & 4.94 & 0.92 & 4.72 & 0.76 & 2.28 & 0.13 & Not Supported \\
H2 (Participating) & 5.19 & 0.72 & 4.43 & 0.69 & 41.05 & 0.00 & Supported \\
H3 (Producing) & 5.51 & 0.64 & 4.12 & 0.86 & 98.54 & 0.00 & Supported \\
\hline
\end{tabular}

ANOVA test gave the P-value of 0.13 , which is not enough for supporting the hypothesis. Then, it as well supports the stated hypothesis of participation in Instagram Storiesthe noticeable distinction between Millennials and Non-Millennials exists. The third hypothesis about the substantial difference between independent's participation in Instagram stories was confirmed and supported by the collected data and analyses as well.

\section{DISCUSSION AND CONCLUSIONS}

Users take it easy when it comes to Instagram Stories - all are quick, relaxed, brief, most of the time more natural and convenient for consumption. Often, sending someone's "Story" to a friend or reply requires just one tap, and knowing that the story is about to disappear, users are more motivated to do that without thinking twice. Moreover, when an individuals' Story is shared with someone (especially when that person is not your follower already), they are instantly getting a visibility boost.

Our research concludes that non-millennials (age 40 and more in 2020) show the same engagement level in watching and reading ephemeral content as Millennials (age 24-39 in 2020). However, Millennials demonstrate statistically significant differences by engaging Instagram "Stories" more frequently communicating and creating content than Nonmillennials.

Our study suggests that Non-millennial users seem to have fresh opportunities to consume Instagram "Stories" as a new opportunity for customer engagement.

\section{Managerial Implications}

Due to the reason of holding smartphones upright, most of the people use it in this position when scrolling; it makes consuming ephemeral content in a vertical position. As a result, the vertical location of the screen where content occupies the whole screen also enables brand managers to post wider content compared square images on Facebook or Instagram timelines. What we can see from study findings, not just millennials, but also non-millennials are willing to engage (consume) this form of content that enables managers to reach and target non-millennial customers too. However, brand managers should be cautious when designing campaigns where non-millennials are involved as a content producer due to lack of ability/knowledge related to the novelty of technology in ephemeral social media.

Content in social media are mostly self-oriented and exists as "me-formers" rather than "informers" when communicating in social media and causes content describes current surroundings or shares personal feelings and opinions. Thus, yet micro-influencers may have the plausibility that some brands actually may not have. In this scenario, it should be beneficial for marketing initiatives to include micro-influencers in ephemeral social networking ("Instagram Stories," "Facebook Stories," "WhatsApp Stories," "YouTube Stories") in order to maximize customer engagement value (CEV). 


\section{Avenues for Future Research}

In our study, we concentrated on the indirect contribution of customers (influence, feedback, exchange of knowledge \& experiences, etc.) to the company, which is the result of emotional attachment (Pansari and Kumar, 2018). However, it will be important to see future researches on how consumers will engage the firm in the form of sales (direct contribution) through ephemeral social media. Apart from direct contribution, at which stage we should describe ephemeral social media as a new touchpoint in the customer's journey that represents authentic consumer experience.

Another insight on consumer engagement in ephemeral social media is psychologically based on the relationship between the customer and the company that may be studied, demonstrating the cognitive, emotional and behavioural status of the consumer through cocreative interaction (Calder et al., 2009; Brodie et al., 2011; Hollebeek, 2011).

In fact, we can conclude that ephemeral social media is not just another social media platform, and therefore it is driven by more emotional bonding.

\subsection{Limitations}

Regardless of the novelty of the research, it has some limitations that could be the reason for future research. One of the main limitations was the number of the participants, for more accurate results for the future researches it should be considered into account. Also, the number of Millennial participants recommended being more, as it was not possible to reach more people from Millennials to take part in a survey. 


\section{REFERENCES}

ALTER, J., (2018). Instagram Engagement Rate Data: Average Seconds On Site | Yotpo. [online] Yotpo. Available at: <https://www.yotpo.com/blog/instagram-engagementrate/> [Accessed 11 July 2018].

BARRY, A.E., BATES, A.M., OLUSANYA, O., VINAL, C.E., MARTIN, E., PEOPLES, J.E., JACKSON, Z.A., BILLINGER, S.A., YUSUF, A., CAULEY, D.A. and MONTANO, J.R., (2016). Alcohol marketing on Twitter and Instagram: Evidence of directly advertising to youth/adolescents. Alcohol and Alcoholism, 51(4), pp.487-492.

BAYER, J., ELLISON, N., SCHOENEBECK, S. and FALK, E., (2015). Sharing the small moments: ephemeral social interaction on Snapchat. Information, Communication \& Society, 19(7), pp.956-977.

BECKERS, S.F., RISSELADA, H. and VERHOEF, P.C., (2014). Customer engagement: A new frontier in customer value management. In: RUST R. T. \& HUANG M.-H. Handbook of service marketing research. Edward Elgar Publishing, pp. 97-122

BELANCHE, D., CENJOR, I. and PÉREZ-RUEDA, A., (2019). Instagram Stories versus Facebook Wall: an advertising effectiveness analysis. Spanish Journal of Marketing ESIC, 23(1), pp.69-94.

BENNETT, S., MATON, K. and KERVIN, L., (2008). The 'digital natives' debate: A critical review of the evidence. British journal of educational technology, 39(5), pp.775-786.

BILLINGS, A.C., QIAO, F., CONLIN, L. and NIE, T., (2017). Permanently desiring the temporary? Snapchat, social media, and the shifting motivations of sports fans. Communication \& Sport, 5(1), pp.10-26.

BRODIE, R., HOLLEBEEK, L., JURIĆ, B. and ILIĆ, A., (2011). Customer Engagement. Journal of Service Research, 14(3), pp.252-271.

CALDER, B., MALTHOUSE, E. and SCHAEDEL, U., (2009). An Experimental Study of the Relationship between Online Engagement and Advertising Effectiveness. Journal of Interactive Marketing, 23(4), pp.321-331.

CASALÓ, L., FLAVIÁN, C. and IBÁÑEZ-SÁNCHEZ, S., (2017). Antecedents of consumer intention to follow and recommend an Instagram account. Online Information Review, 41(7), pp.1046-1063.

CHEN, K. and CHEUNG, H., (2019). Unlocking the power of ephemeral content: The roles of motivations, gratification, need for closure, and engagement. Computers in Human Behavior, 97, pp.67-74.

CHU, S. and KIM, Y., (2011). Determinants of consumer engagement in electronic word-ofmouth (eWOM) in social networking sites. International Journal of Advertising, 30(1), pp.47-75.

CONSTINE, J., (2018). Techcrunch Is Now A Part Of Verizon Media. [online] Techcrunch.com. Available at: <https://techcrunch.com/2018/06/20/instagram-1billion-users/?guccounter=1> [Accessed 8 July 2019].

COOPER, P., (2018). Social Media Advertising Stats That Matter To Marketers In 2018. [online] Hootsuite Social Media Management. Available at: <https://blog.hootsuite.com/social-media-advertising-stats/> [Accessed 6 May 2019]. 
DIMOCK, M., (2019). Defining Generations: Where Millennials End And Generation Z Begins. [online] Pew Research Center. Available at: $<$ https://www.pewresearch.org/fact-tank/2019/01/17/where-millennials-end-andgeneration-z-begins/> [Accessed 9 March 2019].

FINSTAD, K., (2010). Response interpolation and scale sensitivity: Evidence against 5-point scales. Journal of Usability Studies, 5(3), pp.104-110.

FORNELL, C. and LARCKER, D.F., (1981). Evaluating structural equation models with unobservable variables and measurement error. Journal of marketing research, 18(1), pp.39-50.

FRY, R., 2018. Millennials Expected To Outnumber Boomers In (2019). [online] Pew Research Center. Available at: <https://www.pewresearch.org/fact-tank/2018/03/01/millennialsovertake-baby-boomers/> [Accessed 2 March 2019].

FU, P., WU, C. and CHO, Y., (2017). What makes users share content on facebook? Compatibility among psychological incentive, social capital focus, and content type. Computers in Human Behavior, 67, pp.23-32.

FUCHS, C., BOERSMA, K., ALBRECHTSLUND, A. and SANDOVAL, M., (2013). Internet and surveillance: The challenges of Web 2.0 and social media (Vol. 16). Routledge.

GARSON, G.D., (2012). Testing statistical assumptions. Asheboro, NC: Statistical Associates Publishing.

GLOBAL INDEX, 2018. The Latest Social Media Trends To Know In (2018). [online] Globalwebindex.com. Available at: <https://www.globalwebindex.com/reports/social> [Accessed 16 May 2019].

HAIR, J.F., BLACK, W.C., BABIN, B.J., ANDERSON, R.E. and TATHAM, R.L., (1998). Multivariate data analysis (Vol. 5, No. 3, pp. 207-219). Upper Saddle River, NJ: Prentice hall.

HOLLEBEEK, L., (2011). Exploring customer brand engagement: definition and themes. Journal of strategic Marketing, 19(7), pp.555-573.

INSTAGRAM (2016). Introducing Instagram Stories | Instagram Blog. [online] About.instagram.com https://about.instagram.com/blog/announcements/introducing-instagram-stories [Accessed 3 Mar. 2019].

ISRAFILZADE, K., (2017). „Y” Generation Engagement on Consumer-Generated Media: Differences between Lithuania and Azerbaijan. International Journal of Management, accounting and Economics, 4(9), pp.962-979.

JANSZ, J., SLOT, M., TOL, S. and VERSTRAETEN, R., (2015). Everyday creativity: Consumption, participation, production, and communication by teenagers in the Netherlands. Journal of Children and Media, 9(2), pp.143-159.

KAPLAN, A.M. and HAENLEIN, M., (2010). Users of the world, unite! The challenges and opportunities of Social Media. Business horizons, 53(1), pp.59-68.

KLINE, R.B., (2011). Principles and practice of structural equation modeling (Vol. 3rd). New York: Guilford publications.

LUÍS ABRANTES, J., SEABRA, C., RAQUEL LAGES, C. and Jayawardhena, C., (2013). Drivers of in-group and out-of-group electronic word-of-mouth (eWOM). European Journal of Marketing, 47(7), pp.1067-1088. 
MARCUS, S.R., (2015). Picturing'ourselves into being: assessing identity, sociality and visuality on Instagram. In international communication association conference.

MONTEIRO, R. and MAZZILLI, P., (2016). LIVE STORIES O Snapchat como uma pasta compartilhada de registros da vida. Intercom. Sociedade Brasileira de Estudos Interdisciplinares da Comunicação, Salto, pp.1-15.

OECD, (2007). Participative web and user-created content: Web 2.0, wikis, and social networking. Paris: Organisation for Economic Co-operation and Development.

PALMATIER, R. W., KUMAR, V., and HARMELING, C. M., (2018). Customer Engagement Marketing. Cham: Springer International Publishing.

PALMER, A. and KOENIG-LEWIS, N., (2009). An experiential, social network-based approach to direct marketing. Direct Marketing: An International Journal, 3(3), pp.162176.

PANSARI, A. and KUMAR, V., (2017). Customer engagement: the construct, antecedents, and consequences. Journal of the Academy of Marketing Science, 45(3), pp.294-311.

PANSARI, A., \& KUMAR, V. (2018). Customer Engagement Marketing. In: R. W. PALMATIER, V. KUMAR, \& C. M. HARMELING, ed., Customer Engagement Marketing, Cham: Springer International Publishing, pp. 1-27.

PARMENT, A., (2013). Generation Y vs. Baby Boomers: Shopping behavior, buyer involvement and implications for retailing. Journal of retailing and consumer services, 20(2), pp.189-199.

PIWEK, L. and JOINSON, A., (2016). "What do they snapchat about?" Patterns of use in timelimited instant messaging service. Computers in Human Behavior, 54, pp.358-367.

SASHITTAL, H.C., DEMAR, M. and JASSAWALLA, A.R., (2016). Building acquaintance brands via Snapchat for the college student market. Business Horizons, 59(2), pp.193204.

SCHROCK, A.R., (2015). Communicative affordances of mobile media: Portability, availability, locatability, and multimediality. International Journal of Communication, 9, p.18.

SHAO, G., (2009). Understanding the appeal of user-generated media: a uses and gratification perspective. Internet Research, 19(1), pp.7-25

SHELDON, P. and BRYANT, K., (2016). Instagram: Motives for its use and relationship to narcissism and contextual age. Computers in human Behavior, 58, pp.89-97.

STATISTA, (2018). Instagram: active users 2018. [online] Statista.com. Available at: <https://www.statista.com/statistics/253577/number-of-monthly-active-instagramusers/> [accessed 03 May 2019]

STATISTA, (2019a). Global Instagram user age \& gender distribution 2019. [online] Statista.com. Available at: <https://www.statista.com/statistics/248769/agedistribution-of-worldwide-instagram-users/> [accessed 7 July 2019].

STATISTA, (2019b). Instagram Stories daily active users 2019. Statista.com. Available at: <https://www.statista.com/statistics/730315/instagram-stories-dau/> [accessed 11 July 2019].

STEENKAMP, J.B.E. and GEYSKENS, I., (2006). How country characteristics affect the perceived value of web sites. Journal of marketing, 70(3), pp.136-150. 
VAN DOORN, J., LEMON, K.N., MITTAL, V., NASS, S., Pick, D., PIRNER, P. and VERHOEF, P.C., (2010). Customer engagement behavior: Theoretical foundations and research directions. Journal of service research, 13(3), pp.253-266.

VAN NIMWEGEN, C. and BERGMAN, K., (2019). Effects on cognition of the burn after reading principle in ephemeral media applications. Behaviour \& Information Technology, 38(10), pp.1060-1067.

VANDERSLICE, H.N., (2016). How female online businesses and brands are using Instagram stories.

VÁZQUEZ-HERRERO, J., DIREITO-REBOLLAL, S. and LÓPEZ-GARCÍA, X., (2019). Ephemeral Journalism: News Distribution Through Instagram Stories. Social Media+ Society, 5(4), p.2056305119888657.

VIDMOB, (2018). State of Social Video - VidMob. [online] vidmob.com. Available at: <https://www.vidmob.com/state-of-social-video/> [accessed 20 July 2019].

VILLAESPESA, E. and WOWKOWYCH, S. (2020). Ephemeral Storytelling With Social Media: Snapchat and Instagram Stories at the Brooklyn Museum. Social Media + Society, 6(1), p.205630511989877.

VIVEK, S.D., BEATTY, S.E. and MORGAN, R.M., (2012). Customer engagement: Exploring customer relationships beyond purchase. Journal of marketing theory and practice, 20(2), pp.122-146.

WAKEFIELD, L. and BENNETT, G., (2018). Sports fan experience: Electronic word-ofmouth in ephemeral social media. Sport Management Review, 21(2), pp.147-159.

WESNER, M.S. and MILLER, T., (2008). Boomers and millennials have much in common. Organization Development Journal, 26(3), p.89.

XU, B., CHANG, P., WELKER, C., BAZAROVA, N. and COSLEY, D., (2016). Automatic Archiving versus Default Deletion: What Snapchat Tells Us About Ephemerality in Design. Proceedings of the 19th ACM Conference on Computer-Supported Cooperative Work \& Social Computing - CSCW'16,.

YOO, K. and GRETZEL, U., (2011). Influence of personality on travel-related consumergenerated media creation. Computers in Human Behavior, 27(2), pp.609-621.

ZHANG, J. and LEE, W., (2012). Exploring the Influence of Cultural Value Orientations on Motivations of Electronic Word-of-Mouth Communication. Journal of Internet Commerce, 11(2), pp.117-138. 
ISRAFILZADE \& BABAYEV / Millennial versus Non-Millennial Users: Context of Customer Engagement Levels on Instagram Stories (extended version) 